\title{
Absence of Classical Heat Shock Response in the Citrus Pathogen Xylella fastidiosa
}

\author{
Daniel Martins-de-Souza • Gustavo Astua-Monge $\cdot$ Helvécio Della Coletta-Filho • \\ Flavia Vischi Winck · Paulo Aparecido Baldasso - Bruno Menezes de Oliveira • \\ Sérgio Marangoni - Marcos Antônio Machado · José Camillo Novello · \\ Marcus Bustamante Smolka
}

Published online: 13 June 2009

(C) Springer Science+Business Media, LLC 2009

Erratum to: Curr Microbiol (2007) 54:119-123

DOI 10.1007/s00284-006-0215-2

The name of one of the authors of this article (Daniel Martins-de-Souza) was misspelled in the print and online versions published previously. His name is presented correctly here.

The online version of the original article can be found under doi:10.1007/s00284-006-0215-2.

D. Martins-de-Souza - F. V. Winck - P. A. Baldasso ·

B. M. de Oliveira - S. Marangoni · J. C. Novello ( $\square)$.

M. B. Smolka

Departamento de Bioquímica, Inst. de Biologia, UNICAMP,

Campinas, SP, Brazil

e-mail: jen@unicamp.br

G. Astua-Monge $\cdot$ H. D. Coletta-Filho $~ M$ M. A. Machado

Centro APTA Citros Sylvio Moreira/IAC, Cordeirópolis, SP,

Brazil

M. B. Smolka

Department of Cellular and Molecular Medicine, Ludwig Institute for Cancer Research, UCSD, 9500 Gilman Drive,

La Jolla, CA 92093-0653, USA 